\title{
A case of acute respiratory distress syndrome responsive to methylene blue during a carcinoid crisis
}

\section{Un cas de syndrome de détresse respiratoire aiguë répondant au bleu de méthylène pendant une crise carcinoïde}

\author{
Sean van Diepen, MD - Alan Sobey, MD - Richard Lewanczuk, MD, PhD • \\ Gurmeet Singh, MD • Surita Sidhu, MD • Mohamad Zibdawi, MD • \\ John C. Mullen, MD
}

Received: 14 June 2013/Accepted: 15 August 2013/Published online: 14 September 2013

(C) Canadian Anesthesiologists' Society 2013

\begin{abstract}
Purpose In a carcinoid crisis, numerous vasoactive agents, such as bradykinin precursors, serotonin, and histamine, are secreted by tumour cells. Bradykinin has been shown to increase pulmonary vascular permeability and hypotension in animal models; however, little is known about its in vivo effects or targeted pharmacotherapy in a carcinoid crisis. We describe a case of acute respiratory distress syndrome (ARDS) in a carcinoid crisis refractory to conventional antiserotonin and antihistamine therapies. Clinical features A 56-yr-old male with known liver metastases and previous resection of a small intestinal

Author contributions All co-authors have met authorship criteria. Sean van Diepen, Alan Sobey, Richard Lewanczuk, and Mohamad Zibdawi were involved in the conception of the article. Sean van Diepen and Alan Sobey were involved in the design of the article and in the acquisition of data. Sean van Diepen drafted the article. Gurmeet Singh, Surita Sidhu, and John C. Mullen were involved in the acquisition of information. Richard Lewanczuk, Gurmeet Singh, Surita Sidhu, Mohamad Zibdawi, and John C. Mullen were involved in the interpretation of information. Alan Sobey, Richard Lewnczuk, Gurmeet Singh, Surita Sidhu, Mohamad Zibdawi, and John C. Mullen were involved in revisions for important intellectual content.
\end{abstract}

S. van Diepen, MD

Divisions of Critical Care and Cardiology, University of Alberta, Edmonton, AB, Canada

A. Sobey, MD · G. Singh, MD · M. Zibdawi, MD

Division of Critical Care, University of Alberta, Edmonton, AB,

Canada

R. Lewanczuk, MD, PhD

Division of Endocrinology, University of Alberta, Edmonton,

$\mathrm{AB}$, Canada

S. Sidhu, MD

Division of Anesthesia, University of Alberta, Edmonton, AB, Canada carcinoid tumour in 1991 underwent successful tricuspid and pulmonary valve replacements. On postoperative day 10, he developed hypotension, a fever, leukocytosis, and flushing. His hypotension was treated with a $200 \mu \mathrm{g}$ octreotide iv bolus followed by a $150 \mu \mathrm{g} \cdot \mathrm{hr} r^{-1}$ infusion, vasopressin, norepinephrine, and hydrocortisone. He also required tracheal intubation for $A R D S\left(\mathrm{PaO}_{2}: \mathrm{F}_{\mathrm{I}} \mathrm{O}_{2}\right.$ ratio 96). After $72 \mathrm{hr}$ of broad spectrum antibiotics and no clinical improvement, antiserotonin and antihistamine therapies were augmented with cyproheptadine, ranitidine, and serial octreotide boluses with an infusion of $1,500 \mu \mathrm{g} \cdot \mathrm{hr}^{-1}$. These interventions improved his oxygenation $\left(\mathrm{PaO}_{2}: \mathrm{F}_{1} \mathrm{O}_{2}\right.$ ratio 162$)$ and reduced his norepinephrine requirements. Following a methylene blue bolus $\left(1 \mathrm{mg} \cdot \mathrm{kg}^{-1}\right)$ and 12-hr infusion $\left(0.5 \mathrm{mg} \cdot \mathrm{kg}^{-1} \cdot \mathrm{hr}^{-1}\right)$, all vasopressors were discontinued and his oxygenation improved $\left(\mathrm{PaO}_{2}: \mathrm{F}_{1} \mathrm{O}_{2}\right.$ ratio 297).

Conclusion In a patient with a carcinoid crisis and $A R D S$ refractory to conventional therapies, substantial hemodynamic and oxygenation improvements were observed following methylene blue administration. This

J. C. Mullen, MD

Division of Cardiothoracic Surgery, University of Alberta,

Edmonton, AB, Canada

S. van Diepen, MD ( $\square)$

2C2 Cardiology WMC, University of Alberta Hospital,

8440-112 St, Edmonton, AB T6G 2B7, Canada

e-mail:sv9@ualberta.ca 
case highlights the potential pathophysiologic role of bradykinin and methylene blue as an adjunct therapeutic option in carcinoid crises.

\section{Résumé}

Objectif Lors d'une crise carcinoïde, de nombreux agents vasoactifs, y compris les précurseurs de la bradykinine, la sérotonine et l'histamine, sont sécrétés par les cellules tumorales. Il a été démontré que la bradykinine augmentait la perméabilité vasculaire pulmonaire et l'hypotension dans des modèles animaux; toutefois, nous ne connaissons que peu ses effets in vivo ou la pharmacothérapie ciblée pendant une crise carcinoüde. Nous décrivons un cas de syndrome de détresse respiratoire aiguë (SDRA) dans une crise carcinö̈de réfractaire aux traitements conventionnels anti-sérotonine et anti-histamine.

Éléments cliniques Un homme de 56 ans, avec des métastases du foie connues et ayant déjà subi la résection d'une petite tumeur carcinö̈de intestinale en 1991, a subi un remplacement réussi des valves tricuspide et pulmonaire. Au $10^{\text {ème }}$ jour postopératoire, il a manifesté de l'hypotension, de la fièvre, une leucocytose et des bouffées vasomotrices. Son hypotension a été traitée avec un bolus iv de $200 \mu \mathrm{g}$ d'octréotide suivi d'une perfusion de $150 \mu \mathrm{g} \cdot \mathrm{h}^{-1}$, de vasopressine, de norépinéphrine et d'hydrocortisone. Il a également eu besoin d'une intubation trachéale pour son SDRA (ratio $\mathrm{PaO}_{2}: \mathrm{F}_{1} \mathrm{O}_{2}$ 96). Après un traitement à base d'antibiotiques à large spectre de 72 heures, aucune amélioration clinique n'a été observée. Les traitements anti-sérotonine et anti-histamine ont alors été augmentés en ajoutant de la cyproheptadine, de la ranitidine et des bolus d'octréotide en série avec une perfusion de $1500 \mu \mathrm{g} \cdot \mathrm{h}^{-1}$. Ces interventions ont amélioré son oxygénation (ratio $\mathrm{PaO}_{2}: \mathrm{F}_{1} \mathrm{O}_{2}$ 162) et réduit les besoins en norépinéphrine. Après l'administration d'un bolus de bleu de méthylène $\left(1 \mathrm{mg} \cdot \mathrm{kg}^{-1}\right)$ et une perfusion sur $12 \mathrm{~h}$ $\left(0,5 \mathrm{mg} \cdot \mathrm{kg}^{-1} \cdot \mathrm{h}^{-1}\right)$, tous les vasopresseurs ont été cessés et son oxygénation s'est améliorée (ratio $\mathrm{PaO}_{2}: \mathrm{F}_{1} \mathrm{O}_{2}$ 297).

Conclusion Chez un patient en crise carcinoïde et souffrant de SDRA réfractaire aux traitements conventionnels, on a observé d'importantes améliorations au niveau de l'hémodynamie et de l'oxygénation suite à l'administration de bleu de méthylène. Ce cas souligne le rôle physiopathologique potentiel de la bradykinine et du bleu de méthylène comme option thérapeutique additionnelle dans les cas de crise carcinoüde.

Carcinoid tumours are well-differentiated neuroendocrine tumours with an estimated incidence of 1.20-2.12 per 100,000 people. ${ }^{1}$ Metastatic and carcinoid heart disease are thought to be risk factors for the perioperative incidence of carcinoid crises, though the incidence is low among patients who receive the serotonin release inhibitor, octreotide. ${ }^{2,3}$ Carcinoid tumour cells, however, secrete a number of vasoactive agents, including serotonin, histamine, and kallikreins (which convert kininogen into bradykinin). ${ }^{2}$ In a carcinoid crisis, which can manifest as hypotension, flushing, diarrhea, and bronchoconstriction, antiserotonin and antihistamine therapies have been traditional therapeutic options. ${ }^{3}$ Importantly, bradykinin has been shown to increase pulmonary vascular permeability and produce hypotension in animals; however, little is known about pharmacologically modifying its effects in a carcinoid crisis. ${ }^{4-6}$

Herein, we report a severe case of postoperative carcinoid crisis associated with acute respiratory distress syndrome (ARDS) that was refractory to conventional antiserotonin and antihistamine therapies. A rapid improvement in oxygenation and blood pressure was observed following administration of methylene blue, suggesting that methylene blue may be an adjunct treatment for shock and non-cardiogenic pulmonary edema associated with a carcinoid crisis.

\section{Case report}

Written consent for this case report was obtained from the patient. A 56-yr-old male with known liver metastases and symptomatic carcinoid heart disease who underwent resection of a small intestinal carcinoid tumour in 1991 was referred for valve replacement. His carcinoid symptoms were managed with Sandostatin $\mathrm{LAR}^{\mathrm{TM}}$ (40 mg every four weeks) depot injections until being discontinued three months prior to surgery. Preoperative cardiac imaging showed severely thickened and immobile tricuspid and pulmonic valve leaflets associated with severe regurgitation of both valves. The right ventricle was moderately-severely dilated with normal systolic function, and left ventricular systolic function was preserved. The patient underwent successful tricuspid and pulmonic valve replacements with 29-mm Medtronic Mosaic $^{\mathrm{TM}}$ (Medtronic, Minneapolis, MN, USA) porcine valves, and he was managed intraoperatively with an octreotide infusion. Postoperatively, he had multiple selflimiting episodes of hypotension controlled with the addition of an octreotide infusion $100 \mu \mathrm{g} \cdot \mathrm{hr}^{-1}$; he also experienced transient right ventricle failure and acute kidney injury. On postoperative day (POD) 5, he was transferred from the cardiovascular intensive care unit (CVICU) to the ward where his octreotide infusion was discontinued with a plan to resume scheduled monthly Sandostatin LAR injections. 
On POD 10, he was readmitted to the CVICU with hypotension, a fever $\left(38.0{ }^{\circ} \mathrm{C}\right)$, leukocytosis, and flushing. His hypotension was treated with a $200 \mu \mathrm{g}$ octreotide $i v$ bolus followed by a $150 \mu \mathrm{g} \cdot \mathrm{hr}^{-1}$ infusion, vasopressin 0.06 units $\cdot \min ^{-1}, \quad$ norepinephrine $\quad 0.2 \mu \mathrm{g} \cdot \mathrm{kg}^{-1} \cdot \mathrm{min}^{-1}$, milrinone $0.25 \mu \mathrm{g} \cdot \mathrm{kg}^{-1} \cdot \mathrm{min}^{-1}$, and hydrocortisone $50 \mathrm{mg}$ iv q6h. At the time of admission, the patient's laboratory results were as follows: hemoglobin $81 \mathrm{~g} \cdot \mathrm{L}^{-1}$, platelets $161 * 10^{9} \cdot \mathrm{L}^{-1}, \quad$ leukocytes $13.7 * 10^{9} \cdot \mathrm{L}^{-1}, \quad$ sodium $131 \mathrm{mmol} \cdot \mathrm{L}^{-1}$, potassium $4.2 \mathrm{mmol} \cdot \mathrm{L}^{-1}$, creatinine $209 \mu \mathrm{mol} \cdot \mathrm{L}^{-1}$, and lactate $1.6 \mathrm{mmol} \cdot \mathrm{L}^{-1}$. Over sixteen hours, the patient developed progressive hypoxemia requiring tracheal intubation, and he was diagnosed with ARDS $\left(\mathrm{PaO}_{2}: \mathrm{F}_{\mathrm{I}} \mathrm{O}_{2}\right.$ ratio 96 on positive end-expiratory pressure 12 and $\mathrm{F}_{\mathrm{I}} \mathrm{O}_{2} \quad 80 \%$ ). Figure (a) shows the patient's chest $x$-ray prior to tracheal intubation. A noninvasive hemodynamic monitor reported a cardiac index of $4.9 \mathrm{~L} \cdot \mathrm{min}^{-1} \cdot \mathrm{m}^{-2}$ and systemic vascular resistance of 956 dyn sec $\mathrm{cm}^{-5} \mathrm{~m}^{-2}$. An echocardiogram reported a small under-filled and hyperdynamic left ventricle. Tissue Doppler velocities suggested no diastolic dysfunction (septal $\mathrm{e}^{\prime}=10 \mathrm{~cm} \cdot \mathrm{sec}^{-1}$, and lateral $\mathrm{e}^{\prime}=15 \mathrm{~cm} \cdot \mathrm{sec}^{-1}$ ) and normal filling pressures (septal and lateral $\left.\mathrm{E} / \mathrm{e}^{\prime} \leq 8\right){ }^{7}$ The right ventricular midcavity dimension was at the upper limit of normal $(3.3 \mathrm{~cm})$, and the tricuspid annular plane systolic excursion was $1.5 \mathrm{~cm}$ (normal $>1.6 \mathrm{~cm}$ ), suggesting mildly reduced right ventricular systolic function. ${ }^{8}$ Prior to his respiratory deterioration, the patient did not receive blood products, and he denied dysphagia or aspiration. Given the presence of non-cardiogenic pulmonary edema and octreotide refractory hypotension, the patient was initially managed as septic shock and ARDS with broad spectrum antibiotics and low tidal volume ventilation. On POD 13, all preliminary blood, urine, and bronchoscopic alveolar lavage cultures were reported as negative, and an alternate diagnosis of severe carcinoid crisis was considered. The patient was given a 12-mg dose of cyproheptadine followed by $8 \mathrm{mg} \mathrm{NG} \mathrm{q} 8 \mathrm{~h}$ and ranitidine $50 \mathrm{mg} i v$ bid. Additionally, a $500 \mu \mathrm{g}$ and two $250 \mu \mathrm{g} i v$ octreotide boluses were administered, and the infusion was titrated to $1,500 \mu \mathrm{g} \cdot \mathrm{hr}^{-1}$ over a $20-\mathrm{hr}$ period. These interventions improved the patient's oxygenation $\left(\mathrm{PaO}_{2}: \mathrm{F}_{\mathrm{I}} \mathrm{O}_{2}\right.$ ratio 162) and substantially reduced norepinephrine requirements. A $1 \mathrm{mg} \cdot \mathrm{kg}^{-1}$ bolus of methylene blue followed by a $0.5 \mathrm{mg} \cdot \mathrm{kg}^{-1} \cdot \mathrm{hr}^{-1}$ infusion over $12 \mathrm{hr}$ was administered. Six hours after the infusion was completed, all vasopressors were discontinued and the $\mathrm{PaO}_{2}: \mathrm{F}_{\mathrm{I}} \mathrm{O}_{2}$ ratio had increased to 297 . The patient's trachea was extubated on POD 19, and he was discharged to the ward on POD 26. The patient's chest $x$-ray on POD 30 is shown in Figure (b). The patient was discharged home on Sandostatin LAR $30 \mathrm{mg}$ depot every three weeks.

\section{Discussion}

This case report has two important findings. First, it builds on previously published reports of ARDS associated with carcinoid crisis by non-invasively quantifying left ventricular function and filling pressures. Second, we observed a substantial improvement in the patient's blood pressure and oxygenation when methylene blue was added to conventional carcinoid crisis therapies.

In a carcinoid crisis, tumour cells have multiple secretory products; though traditional therapeutic options have targeted only serotonin and histamine. ${ }^{2}$ In animal models, bradykinin causes increased pulmonary vascular permeability, vasodilation, and hypotension. ${ }^{4-6}$ These actions may be mediated in part through the activation of nitric oxide synthase. ${ }^{9,10}$ Methylene blue competitively inhibits the binding of nitric oxide to soluble guanylate cyclase, thereby preventing the downstream activation of cyclic guanosine monophosphate and smooth muscle relaxation. ${ }^{11}$ A previous in vivo animal study has shown
Figure Chest $x$-rays on (a) postoperative day 10 prior to tracheal re-intubation and on (b) postoperative day 30
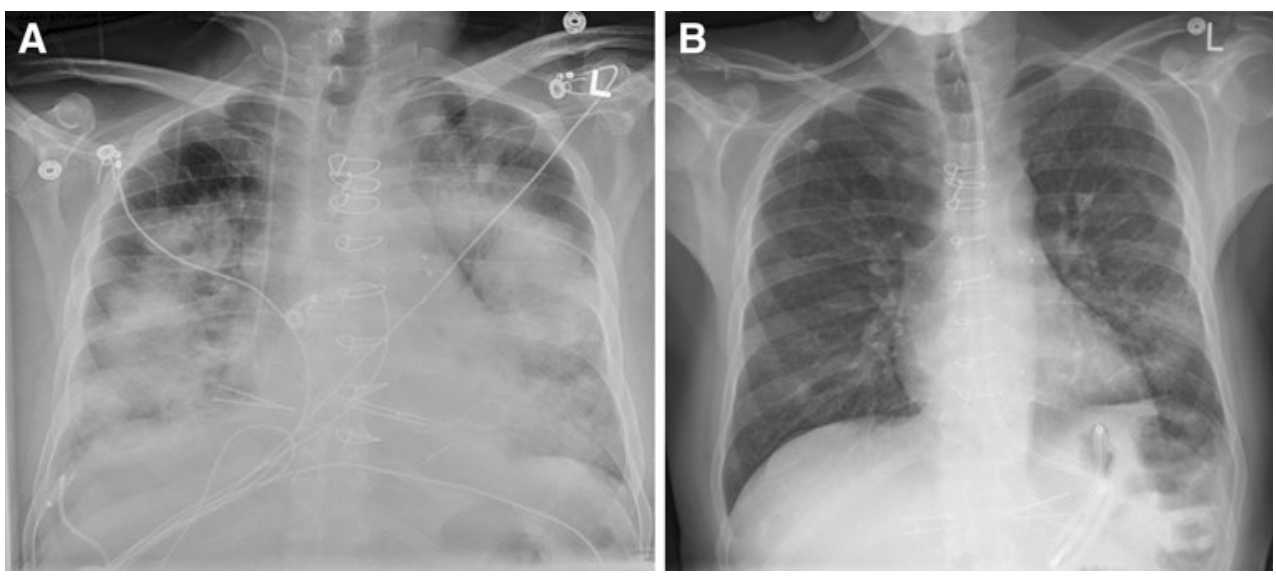
that methylene blue significantly reduces the pulmonary vasodilatory response of bradykinin, though all studies have not supported this finding. ${ }^{12,13}$

The association between ARDS and carcinoid crisis has not been well described. A case of intraoperative noncardiogenic pulmonary edema occurring after mobilization of a pancreatic tumour has been reported in a 28 -yr-old female who rapidly responded to intravenous furosemide monotherapy. ${ }^{14}$ This case builds on this possible association by noninvasively quantifying left ventricular diastolic function, left ventricular end diastolic pressure, and the $\mathrm{PaO}_{2}: \mathrm{F}_{1} \mathrm{O}_{2}$ ratio required for the diagnosis of ARDS. ${ }^{15}$ Finally, the possible association between carcinoid crisis and ARDS in this case report is strengthened by attempts to exclude other common inhospital precipitants of ARDS.

This report also adds to the limited published experience of the use of methylene blue in carcinoid crises. In a previous report of a 74-yr-old male with carcinoid heart disease who developed refractory vasoplegic shock following tricuspid valve replacement, the administration of methylene blue $\left(2 \mathrm{mg} \cdot \mathrm{kg}^{-1}\right.$ over $30 \mathrm{~min}$ then $0.5 \mathrm{mg} \cdot \mathrm{kg}^{-1} \cdot \mathrm{hr}^{-1}$ for six hours) resulted in the discontinuation of all vasopressors. ${ }^{16} \mathrm{In}$ this case, we hypothesize that elevated levels of bradykinin may have been a pathophysiologic mediator of this patient's ARDS and hypotension given the observed hemodynamic and oxygenation improvement following the addition of methylene blue to appropriate antiserotonin and antihistamine therapy.

The limitations of this case report merit consideration. First, the secretory products of the carcinoid tumour were not measured, thus a definitive pathophysiologic link between potential ARDS mediators and therapies cannot be established. Second, the patient showed clinical improvement prior to the administration of methylene blue, thus, some of the improvement may have been a continued response to conventional carcinoid crisis therapies.

In conclusion, this report adds to the limited descriptions of ARDS associated with carcinoid crises and to the limited published experience of methylene blue in carcinoid crises. We observed a rapid clinical improvement in a patient's oxygenation and blood pressure when methylene blue was added to conventional carcinoid crisis therapies. Future studies are required to determine optimal dosing and indications for methylene blue administration in carcinoid crises.

Funding sources None.

Conflicts of interest None declared.

\section{References}

1. Modlin IM, Sandor A. An analysis of 8305 cases of carcinoid tumors. Cancer 1997; 79: 813-29.

2. Anderson AS, Krauss D, Lang R. Cardiovascular complications of malignant carcinoid disease. Am Heart J 1997; 134: 693-702.

3. Kinney MA, Warner ME, Nagorney DM, et al. Perianaesthetic risks and outcomes of abdominal surgery for metastatic carcinoid tumours. Br J Anaesth 2001; 87: 447-52.

4. Wang Y, Soukhova $G$, Proctor M, Walker J, Yu J. Bradykinin causes hypotension by activating pulmonary sympathetic afferents in the rabbit. J Appl Physiol 2003; 95: 233-40.

5. Pang LM, O'Brodovich HM, Mellins RB, Stalcup SA. Bradykinininduced increase in pulmonary vascular permeability in hypoxic sheep. J Appl Physiol 1982; 52: 370-5.

6. Hulstrom D, Svensjo E. Intravital and electron microscopic study of bradykinin-induced vascular permeability changes using FITC-dextran as a tracer. J Pathol 1979; 129: 125-33.

7. Nagueh SF, Appleton CP, Gillebert TC, et al. Recommendations for the evaluation of left ventricular diastolic function by echocardiography. Eur J Echocardiogr 2009; 10: 165-93.

8. Rudski LG, Lai WW, Afilalo J, et al. Guidelines for the Echocardiographic Assessment of the Right Heart in Adults: A Report from the American Society of Echocardiography: Endorsed by the European Association of Echocardiography, a registered branch of the European Society of Cardiology, and the Canadian Society of Echocardiography. J Am Soc Echocardiogr 2010; 23: 685-713.

9. Harris $M B, J u H$, Venema VJ, et al. Reciprocal phosphorylation and regulation of endothelial nitric-oxide synthase in response to bradykinin stimulation. J Biol Chem 2001; 276: 16587-91.

10. Bogle $R G$, Coade SB, Moncada S, Pearson JD, Mann GE. Bradykinin and ATP stimulate L-arginine uptake and nitric oxide release in vascular endothelial cells. Biochem Biophys Res Comm 1991; 180: 926-32.

11. Shanmugam $G$. Vasoplegic syndrome-the role of methylene blue. Eur J Cardiothorac Surg 2005; 28: 705-10.

12. Hyman AL, Kadowitz PJ, Pippton HL. Methylene blue selectively inhibits pulmonary vasodilator responses in cats. J Appl Physiol 1989; 66: 1513-7.

13. Shapiro MB, Endredi J, Ernhart IC, Hofman WF. Methylene blue restores vasodilation to bradykinin after inhibition of nitric oxide production in the isolated dog lung. J Vasc Res 1996; 33: 340-5.

14. Mtaallah M, Boussofara M, Boussen H, Rahal K. Operative noncardiogenic pulmonary oedema and pancreatic carcinoid tumour. Anaesth Intensive Care 2007; 25: 139-40.

15. ARDS Definition Task Force; Ranieri VM, Rubenfeld GD, Thompson BT, et al. Acute respiratory distress syndrome: the Berlin definition. JAMA 2012; 307: 2526-33.

16. Raikhelkar JK, Weiss AJ, Maysick L, Scurlock C. Adjuvant therapy with Methylene Blue in the treatment of postoperative vasoplegic syndrome caused by carcinoid crisis after tricuspid valve replacement. J Cardiothorac Vasc Anesth 2012; 26: 878-9. 